\title{
Change of Erythrocytes Transport Function in Blood of Men with Prostate Adenocarcinoma (before and after Plastic Orchiectomy)
}

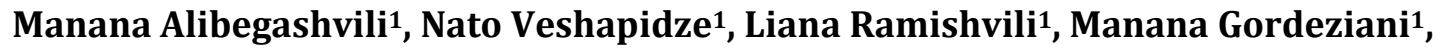 \\ Teimuraz Chigogidze², Nino Gabunia², Ana Khazaradze1, Nanuli Kotrikadze1 \\ ${ }^{1}$ Department of Biology, Faculty of Exact and Natural Sciences, Ivane Javakhishvili Tbilisi State University, \\ Tbilisi, Georgia \\ ${ }^{2}$ Department of Urology, Faculty of Medicine, Ivane Javakhishvili Tbilisi State University, Tbilisi, Georgia \\ Email: nkotrikadze@gmail.com
}

Received 17 November 2015; accepted 20 December 2015; published 23 December 2015

Copyright (C) 2015 by authors and Scientific Research Publishing Inc.

This work is licensed under the Creative Commons Attribution International License (CC BY). http://creativecommons.org/licenses/by/4.0/

(c) (7) Open Access

\begin{abstract}
The changes of blood erythrocytes transport function in patients with prostate adenocarcinoma have been studied according to alterations in $\mathrm{Na}^{+} / \mathrm{K}^{+}$-ATP-ase activity and permeability of $\mathrm{Na}^{+}$and $\mathrm{K}^{+}$ions, before and after the plastic orchiectomy. The results of the study revealed that activity of $\mathrm{Na}^{+} / \mathrm{K}^{+}$-ATP-ase was increased compared with the data before the orchiectomy, but this parameter was reduced compared with control group. The increased amounts of the $\mathrm{Na}^{+}$as well as $\mathrm{K}^{+}$ions were also observed in the extracellular area compared with the same data before the orchiectomy. The amount of cholesterol, after plastic orchiectomy, was reduced compared with the data gained before orchiectomy, but the data were greater than those of the control group. It may be presumed that one of the reasons for change of $\mathrm{Na}^{+} / \mathrm{K}^{+}$-ATP-ase activity is variation of cholesterol content in erythrocyte membrane. Changes of the active transport system, in turn, affect the transport function of the erythrocyte membrane. In spite of surgical intervention, full recovery of patients does not take place after the plastic orchiectomy. Comparative normalization and approaching to the control group of the given indices in post-operation period ( 6 months after surgery) indicate strengthening of the immune system and correspondingly-protective abilities of an organism, which was proved by the anamneses of patients.
\end{abstract}

\section{Keywords}

Prostate Tumors, Plastic Orchiectomy, $\mathrm{Na}^{+} / \mathrm{Ka}^{+}$-ATP-ase

How to cite this paper: Alibegashvili, M., Veshapidze, N., Ramishvili, L., Gordeziani, M., Chigogidze, T., Gabunia, N., Khazaradze, A. and Kotrikadze, N. (2015) Change of Erythrocytes Transport Function in Blood of Men with Prostate Adenocarcinoma (before and after Plastic Orchiectomy). Journal of Cancer Therapy, 6, 1249-1253. 


\section{Introduction}

$\mathrm{Na}^{+} \backslash \mathrm{K}^{+}$-ATP-ase belongs to the transporter family of P-type ATP-ases [1]. It’s known that the enzyme performs the signaling function in addition to the transport function [1] [2]. $\mathrm{Na}^{+} / \mathrm{K}^{+}$-ATP-ase interacts with neighboring membrane proteins and organized cytosolic cascades of signaling proteins to send messages to the intracellular organelles [3] and thus effects the expression of various genes, proliferation of cells, activation of some hormones and growth factors and phosphorylation of certain proteins [4].

$\mathrm{Na}^{+} \backslash \mathrm{K}^{+}$-ATP-ase is exposed in highly specialized cells, such as erythrocytes [5]. Considering the fact that it is easy to extract and to investigate, erythrocyte membrane serves as a unique model for performing membrane investigations. So erythrocytes can be used as a model in the study of $\mathrm{Na}^{+} \backslash \mathrm{K}^{+}$-ATP-ase activity research in biomembranes [6].

Plastic orchiectomy [7], as one of the most common treatments for prostate progressive cancer, implies regression of malignant tumor by means of androgen deprivation. It must be mentioned that application of this surgical method is palliative and does not mean a full recovery of patients [8]. If we take into account that in some cases the surgical treatment causes mutation of the cancer into a hormone-resistant form (which is characteristic with high aggression and metastases) [9], it becomes clear that in spite of some achievements in progressive cancer therapy, yet many problems remain to be solved.

Considering all the above mentioned, the main purposes of our investigation at this stage of the research were to study the changes of transport function of blood erythrocytes in patients with cancer of prostate (CaP) according to the alterations in $\mathrm{Na}^{+} / \mathrm{K}^{+}$-ATP-ase activity and permeability of $\mathrm{Na}^{+}$and $\mathrm{K}^{+}$ions, both before and after the orchiectomy, to make comparative analysis of pre- and post-operative results, and also to reveal the post-operative characteristics of disease according to gained results.

\section{Materials and Methods}

\subsection{Materials}

The erythrocytes of the patients with metastatic prostate cancer (before and after 6 months from castration) served as material for the studies.

Each study group, as well as control group, consisted of 15 patients of ages 60 - 75. Patients were not receiving any type of treatment during sample collection for this investigation.

The patients of the study groups were selected by the following criteria: Patients belonged to the same age group (60 - 75) and all patients belonged to the Caucasian race. Without therapy treatment, the analyses were done after the first reveal of the disease. Clinical stage of the disease of all patients has been diagnosed at the Al. Tsulukidze National Center of Urology (Georgia) by the rectal, histological and echographic investigations of prostate gland; Patients were of the similar anamnesis; Control group consisted of 15 practically healthy men of the same age group and same Caucasian race.

The Ethics Committee of Georgia approved the study and informed consent was obtained from each patient.

The blood samples were obtained before the surgery and after 6 months from castration at the National Centre of Urology (Georgia).

\subsection{Methods}

Gaining of the erythrocyte membranes was performed by the method of Dodge [10]. Erythrocyte suspension was lysed using $20 \mathrm{mmol} / \mathrm{l}$ of phosphate buffer of $\mathrm{pH} 7.4$ and centrifuged. Then, the procedure was repeated using the same solution of the concentration $10 \mathrm{mmol} / \mathrm{l}$ and $5 \mathrm{mmol} / \mathrm{l}$ in order to wash off the haemoglobin from the erythrocyte ghosts.

Protein concentration was detected by the method of Lowry [11].

$\mathrm{Na}^{+}, \mathrm{K}^{+}$-ATP-ase activity determination method was based on the spectrophotometric determination (635 nm) of free orthophosphate (Pi) released due to the $\mathrm{Na}^{+}, \mathrm{K}^{+}$-ATP-ase catalyzed hydrolysis of ATP. Pi is usually transformed to a phosphomolybdate complex in an acid medium followed by a reduction with ascorbic acid followed by complexation with basic dyes that yield colored complexes. Specific activity of the enzyme was expressed as $\mu \mathrm{mol}$ of Pi released per min per mg of protein [12].

$\mathrm{Na}^{+}$and $\mathrm{K}^{+}$ions were studied by ionometric method [13].

The concentration of cholesterol was determined by using Liebermann-Burchard reagent spectrophotometri- 
cally at $635 \mathrm{~nm}[14]$.

Experimental data were processed by means of standard variation statistics MINITAB (Basic statistic) $\mathrm{P}<$ 0.05 was taken as statistically significant.

\section{Results and Discussion}

Investigations have revealed the changes in $\mathrm{Na}^{+} / \mathrm{K}^{+}$-ATP-ase activity in blood erythrocytes of CaP patients after the plastic orchiectomy. In particular, the index increased compared to the data of pre-operation period [15], but it remained lower than the control variant (Table 1). At the same time, increase of concentration of $\mathrm{Na}^{+}$and $\mathrm{K}^{+}$ ions in extracellular area was observed. Though, both-the enzyme activity and ion concentration remained lower compared to similar indices of the control group (Table 1).

It is established that there is a two-side relationship between $\mathrm{Na}^{+} / \mathrm{K}^{+}$-ATP-ase activity and concentration of $\mathrm{Na}^{+}$and $\mathrm{K}^{+}$ions. In particular, $\mathrm{Na}^{+} / \mathrm{K}^{+}$-ATP-ase is the main enzyme regulating the concentration gradient of $\mathrm{Na}^{+}$ and $\mathrm{K}^{+}$ions in intra- and extra-cellular areas; But mentioned ions, in turn, play the role of enzyme's regulators [1] [16].

Thus, decrease of $\mathrm{Na}^{+} / \mathrm{K}^{+}$-ATP-ase activity in membrane of erythrocytes, compared to the control group, which was revealed in CaP cases both, before and after orchiectomy, may be somehow connected with the decrease of $\mathrm{K}^{+}$ion concentration in extracellular area. It is known that increased concentrations of $\mathrm{K}^{+}$ions suppress the inhibitory effect of ouabain, causing the rise of enzyme's activity [13]. Taking into account the above mentioned, it may be supposed that one of the reasons for decreased $\mathrm{Na}^{+} / \mathrm{K}^{+}$-ATP-ase activity (compared to the control group) in case of $\mathrm{CaP}$, both before and after orchiectomy, may be the reduction of $\mathrm{K}^{+}$ion concentration in the surrounding medium (which was expressed more clearly before the orchiectomy). Presumably accumulation of $\mathrm{K}^{+}$ions in the extracellular area is insufficient for reducing the inhibitory effect of ouabain. As a result $\mathrm{Na}^{+} / \mathrm{K}^{+}$-ATP-ase inhibition takes place in case of the mentioned pathology (this was expressed more clearly before the orchiectomy) (Table 1) [15].

As for changes of $\mathrm{Na}^{+}$ion concentration in the extracellular area, we suppose that while suppressing $\mathrm{Na}^{+} / \mathrm{K}^{+}$ATP-ase activity, ouabain causes transport of insignificant amount of $\mathrm{Na}^{+}$ions into the extracellular area, which was revealed as a decrease of $\mathrm{Na}^{+}$ion concentration (compared to the control group) both before and after orchiectomy (Table 1). This result was especially evident in pre-orchiectomy data. Our supposition is based on data demonstrating the linear relation between changes of $\mathrm{Na}^{+}$ion concentration in the extracellular area and alterations in enzyme's transport function [17], and also is supported by our previous results [15] (Table 1).

It is known that in addition to the ion pumps, transport of substances to intra- and extra cellular areas is provided by passive and secondary active transport processes. Moreover, the conjugated functioning of the primary and secondary active transport through the membrane is also possible [1]. Taking into account the above mentioned supposition, it becomes clear that changes in $\mathrm{Na}^{+}$and $\mathrm{K}^{+}$ion transport abilities of erythrocyte membrane (which in case of CaP was revealed by the reduced amount of the ions in the extracellular area, both before and after plastic orchiectomy) must be determined not only by the inhibition of $\mathrm{Na}^{+} / \mathrm{K}^{+}$-ATP-ase activity, but the role of passive and secondary active transport must also be taken into account. Possibly, in case of CaP, the total transport system functioning is generally deregulated, which is reflected on the transport function of erythrocytes.

According to above mentioned, we suppose that decreasement of $\mathrm{Na}^{+} / \mathrm{K}^{+}$-ATP-ase activity and changes of $\mathrm{Na}^{+}$and $\mathrm{K}^{+}$ion concentration in case of CaP, both before and after orchiectomy, reflects the general changes of a cancer-damaged organism and impaired reaction of its controlling systems against the cancer pathology.

Table 1. Alterations of $\mathrm{Na}^{+}, \mathrm{K}^{+}$-ATP-ase activity, ions permeability and cholesterol amount in red blood cells.

\begin{tabular}{ccccc}
\hline Object (tumor tissue) & $\mathbf{N a}^{+}, \mathbf{K}^{+}$-ATP-ase activity $\mu \mathbf{M} / \mathbf{m i n}$ (mg/protein) & $\mathbf{1}_{\mathbf{p N a}}^{+-}$ & $\mathbf{1 / \mathbf { p K } ^ { + }}$ & $\mathbf{C h o l e s t e r o l ~ ( m g / \% ) ~}^{+}$ \\
\hline Control group & $0.546 \pm 0.2$ & $0.66 \pm 0.01$ & $0.45 \pm 0.002$ \\
CaP (before castration) [15] & $0.28 \pm 0.1$ & $0.48 \pm 0.02$ & $0.38 \pm 0.001$ & $572 \pm 0.01$ \\
CaP (after castration) & $0.335 \pm 0.1$ & $0.53 \pm 0.01$ & $0.40 \pm 0.001$ \\
\hline
\end{tabular}

$\mathrm{n}=15$ (the amount of the patients in each group); $\mathrm{P} \leq 0.05$. 
Comparative normalization of above mentioned indices (compared to pre-operation data) after the 6 month from orchiectomy may indicate to a partial recovery of the general condition of an organism and its homeostasis [6].

Next step of investigations comprised the study of cholesterol content in membrane of erythrocytes both, before and after orchiectomy.

It is well known that there is a direct relationship between the cholesterol concentration, $\mathrm{Na}^{+} / \mathrm{K}^{+}$-ATP-ase activity and changes of $\mathrm{Na}^{+}$and $\mathrm{K}^{+}$ion transport function in erythrocyte membranes [18]. Moreover, cholesterol is responsible for membrane fluidity. Rise of the cholesterol content in membrane until it reaches the determined level is due to the increase of micro viscosity [18]. Enzyme $\mathrm{Na}^{+} / \mathrm{K}^{+}$-ATP-ase, in turn, responds to alteration of membrane viscosity by a change in its activity [19] [20].

Decrease of cholesterol content in erythrocyte membrane after the plastic orchiectomy, compared to pre- operation data, was revealed by experimental results. But the index was higher compared to the results of the control group (Table 1). As the amount of cholesterol in erythrocyte membrane after orchiectomy was mean value between norm (control group) and pathology (CaP), activity of $\mathrm{Na}^{+} / \mathrm{K}^{+}$-ATP-ase correspondingly would be intermediate, which was proved by our investigations as well (Table 1 ).

Thus, according to our studies and literary data it may be presumed that one of the reasons for $\mathrm{Na}^{+} / \mathrm{K}^{+}$ATP-ase activity change is alteration of cholesterol content in erythrocyte membranes. Changes of the active transport system, from its side, affect the transport function of the erythrocyte membrane.

\section{Conclusions}

It has been revealed that after plastic orchiectomy $\mathrm{Na}^{+} / \mathrm{K}^{+}$-ATP-ase activity as well as the amount of $\mathrm{Na}^{+}$and $\mathrm{K}^{+}$ ions in the extracellular area is increased compared with the results gained before the orchiectomy.

It has been revealed that reduced cholesterol content in erythrocyte membrane after plastic orchiectomy, compared with the same data before orchiectomy, should lead to increased activity of $\mathrm{Na}^{+} / \mathrm{K}^{+}$-ATP-ase.

After orchiectomy the systemic effect of cancer on erythrocyte membranes of CaP patients is revealed by the number of alterations such as changes in cholesterol content, alterations of lipid peroxidation intensity [21] and morphological changes of erythrocytes [22]. All these alterations affect the transport function of erythrocyte membrane.

In spite of surgical intervention, full recovery of patients does not take place after the orchiectomy, because of the residual phenomena.

Comparative normalization and approaching of the studied indices gained in post-operation period (6 months after operation) to the control group data indicate strengthening of immune system and correspondingly-protective abilities of an organism, which was proved by the anamneses of patients.

\section{References}

[1] Pratap, P.R., Dediu, O. and Nienhaus, G.U. (2003) FTIR Study of ATP-Induced Changes in $\mathrm{Na}^{+} / \mathrm{K}^{+}$-ATPase from Duck Supraorbital Glands. Biophysical Journal, 85, 3707-3717. http://dx.doi.org/10.1016/S0006-3495(03)74787-0

[2] Xie, Z. and Cai, T. (2003) $\mathrm{Na}^{+} /-\mathrm{K}^{+}$-ATP-asa-Mediated Signal Transduction: From Protein Interaction to Cellular Function. Molecular Interventions, 3, 157-168. http://dx.doi.org/10.1124/mi.3.3.157

[3] Yoon, T., Kim, M. and Lee, K. (2006) Inhibition of Na,K-ATPase-Suppressive Activity of Translationally Controlled Tumor Protein by Sorting Nexin 6. FEBS Letters, 580, 3558-3564. http://dx.doi.org/10.1016/j.febslet.2006.05.042

[4] Pressley, T.A. (1992) Ionic Regulation of $\mathrm{Na}^{+} /-\mathrm{K}^{+}$-ATP-ase Expression. Seminars in Nephrology, 12, 67-71.

[5] Staines, H.M., Ellory, J.C. and Kirk, K. (2001) Perturbation of the Pump-Leak Balance for Na and K in Malaria-Infected Erythrocytes. Journal of Cellular Physiology, 280, 1576-1587.

[6] Alevizopoulos, K., Calogeropoulou, T., Lang, F. and Stournaras, C. (2014) $\mathrm{Na}^{+} / \mathrm{K}^{+}$ATPase Inhibitors in Cancer. Current Drug Targets, 15, 988-1000.

[7] Riba, L.W. (1942) Subcapsular Castration for Carcinoma of Prostate. Journal of Urology, 48, 384-387.

[8] Gingrich, J.R., Barrios, R.J. and Kattan, M.W. (1997) Androgen-Independent Prostate Cancer Progression in the TRAMP Model. Journal of Cancer Research, 57, 4687-4691.

[9] Schulz, W.A., Burchardt, M. and Cronauer, M.V. (2003) Molecular Biology of Prostate Cancer. Molecular Human Reproduction, 9, 437-448. http://dx.doi.org/10.1093/molehr/gag064

[10] Dodge, J.T., Mitchell, C. and Hanahan, D.J. (1963) The Preparation and Chemical Characteristics of Hemoglobin-Free Ghosts of Human Erythrocytes. Archives of Biochemistry and Biophysics, 100, 119-130. 
http://dx.doi.org/10.1016/0003-9861(63)90042-0

[11] Lowry, O.H., Rosebrough, N.J., Farr, A.L. and Randall, R.J. (1951) Protein Measurement with the Folin Phenol Reagent. The Journal of Biological Chemistry, 193, 265-275.

[12] Stolz, M., Lewitzki, E., Mantele, W., Barth, A. and Grell, E. (2006) Inhibition and Partial Reactions of Na,K-ATPase Studied by Fourier Transform Infrared Difference Spectroscopy. Biopolymers, 82, 368-372. http://dx.doi.org/10.1002/bip.20427

[13] Lishko, V., Malyshev, M. and Grevizyrskaya, T. (1974) The Study of Membrane Na,K-ATPase and Erythrocytes' Ghosts Interactions by Ouabain. The Journal of Biochemistry, 39, 60-66. (In Russian)

[14] Filipovich, U.B., Egorova, T.A. and Sevastianov, G.A. (1975) General Biochemistry Practical. p. 278.

[15] Alibegashvili, M. (2003) Investigation of Membrane Regulation Changes in Blood Erythrocytes during Tumor Growth (Prostate Benign Hyperplasia, Prostate Adenocarcinoma). PhD Thesis, Tbilisi.

[16] McFarland, R., Zanjani, H.S., Mariani, J. and Vogel, M.W. (2014) Changes in the Distribution of the $\alpha 3 \mathrm{Na}^{+} / \mathrm{K}^{+} \mathrm{AT}-$ Pase Subunit in Heterozygous Lurcher Purkinje Cells as a Genetic Model of Chronic Depolarization during Development. International Journal of Cell Biology, 2014, Article ID: 152645. http://dx.doi.org/10.1155/2014/152645

[17] Pchejetski, D., Taurin, S., Der Sarkissian, S., Lopina, O.D., Pshezhetsky, A.V., Tremblay, J., et al. (2003) Inhibition of $\mathrm{Na}^{+}, \mathrm{K}^{+}$-ATPase by Ouabain Triggers Epithelial Cell Death Independently of Inversion of the $\left[\mathrm{Na}^{+}\right]_{\mathrm{i}} /\left[\mathrm{K}^{+}\right]_{\mathrm{i}}$ Ratio. Biochemical and Biophysical Research Communications, 301, 735-744. http://dx.doi.org/10.1016/S0006-291X(02)03002-4

[18] Kolanjiappan, K., Manoharan, S. and Kayalvizhi, M. (2002) Measurement of Erythrocyte Lipids, Lipid Peroxidation, Antioxidants and Osmotic Fragility in Cervical Cancer Patients. Clinica Chimica Acta, 326, 143-149. http://dx.doi.org/10.1016/S0009-8981(02)00300-5

[19] Mangialavori, I., Montes, M.R., Rossi, R.C., Fedosova, N.U. and Rossi, J.P. (2011) Dynamic Lipid-Protein Stoichiometry on $E_{1}$ and $E_{2}$ Conformations of the $\mathrm{Na}^{+} / \mathrm{K}^{+}$-ATPase. FEBS Letters, 585, 1153-1157. http://dx.doi.org/10.1016/j.febslet.2011.03.024

[20] Calderón Guzmán, D., Hernández García, E., Juárez Jacobo, A., Segura Abarca, L., Barragán Mejía, G., Rodríguez Pérez, R., et al. (2011) Effect of Orlistat on Lipid Peroxidation, $\mathrm{Na}^{+}, \mathrm{K}^{+}$ATPase, Glutathione and Serotonin in Rat Brain. Proceedings of the Western Pharmacology Society, 54, 73-77.

[21] Kotrikadze, N., Alibegashvili, M., Zibzibadze, M., Abashidze, N., Chigogidze, T., et al. (2008) Activity and Content of Antioxidant Enzymes in Prostate Tumors. Experimental Oncology, 30, 244-247.

[22] Kotrikadze, N., Veshapidze, N., Ramishvili, L., Alibegashvili, M., Gordeziani, M., et al. (2014) Prognostic Value of Structural and Ultra-Structural Changes of Erythrocytes. Urology, 84, S291. 